\title{
ON THE GENUS LESKEA (LESKEACEAE, BRYOPHYTA) IN RUSSIA
} РОД LESKEA (LESKEACEAE, BRYOPHYTA) IN RUSSIA

\author{
MiCHAEL S. IGNATOV ${ }^{1,2}$, ANDREY G. BEZGODOV ${ }^{3}$, OXANA I. KUZNETSOVA ${ }^{2}$ \& ELENA A. IGNATOVA ${ }^{1}$ \\ МИХАИЛ С. ИГНАТОВ ${ }^{1,2}$, АНДРЕЙ Г. БЕЗГОДОВ ${ }^{3}$, ОКСАНА И. КУЗНЕЦОВА ${ }^{2}$, ЕЛЕНА А. ИГНАТОВА ${ }^{1}$
}

Abstract

The genus Leskea in Russia is represented by one widespread species, L. polycarpa Hedw. Records of $L$. gracilescens appeared to be erroneous. Analysis of nuclear ITS sequence data demonstrated that North American samples of L. gracilescens and L. obscura clearly differ from European and Asian populations in several characteristic substitutions. Anomalous morphology of plants from Yakutia and Amur Province is described and illustrated. Their distribution likely corresponds to a high and late floodings of big rivers, crossing permafrost areas.

Резюме

Род Leskea представлен в России одним широко распространенным видом, L. polycarpa Hedw. Указания на находки L. gracilescens в Амурской области были ошибочными. Анализ нуклеотидных последовательностей ядерного спейсера ITS показал, что североамериканские образцы L. gracilescens and L. obscura отличаются несколькими заменами от европейских и азиатских растений. Необычная морфология растений L. polycarpa из Амурской области и Якутии, вероятно, связана с сильными поздними паводками на больших реках, протекающих в зоне вечной мерзлоты.

KEYWORDS: Leskea, Russian Far East, Yakutia, ecomorphs

\section{INTRODUCTION}

The genus Leskea in Russia included just one species, L. polycarpa Hedw., in almost all publications (Abramov \& Volkova, 1998; Abramova et al., 1961; Ignatov, Afonina, Ignatova et al., 2006). Although Hedwig (1801) described from Europe two species, L. polycarpa and $L$. paludosa, the latter one was considered as a variety of the former already by authors of 19th century (e.g. Schimper, 1860). Eleven infraspecific taxa within Leskea polycarpa are listed in Torpicos database (http:// www.tropicos.org/namesearch.aspx, accessed 1 May 2018), but in recent checklists (Hill et al., 2006; Ros et al., 2013) and Floras (Brugués \& Ruiz, 2018; Redfearn, 2014) they are usually not mentioned at all. Leskea latifolia Lindb. ex Broth., described from the Caucasus (Brotherus, 1892), was synonymized with Amblystegium varium (Abramov, 1969).

In the course of the flora inventory studies in the Nature Reserve «Norsky», Amur River basin in the Russian Far East, we recently reported Leskea gracilescens (Bezgodov et al., 2013), as these plants were sufficiently different, agreeing in many characters with this species as it was circumscribed in moss floras of North America (Redfearn, 2014; Crum \& Anderson, 1981) and espe- cially moss flora of China (Cao et al., 2002). In China this species was reported only recently from its NE part, on the right bank of Amur River in a relatively close proximity to the area where the mentioned Russian collection has been done. Chinese collections were reported as sterile (Cao et al., 2002), while in Russian specimens sporophytes were immature, thus the sporophyte characters were impossible to use. However, catenulate foliage, smaller stem leaves with the smaller length to width ratio, straight and symmetric leaves, lacking characteristic obligue apical part, and occasionally blunt apices in both stem and branch leaves fitted the description of $L$. gracilescens.

Later in Yakutia, to the north of Amur Province, we collected Leskea with even more obtuse leaves, more similar to another American species, L. obscura. So we decided to test with DNA markers if the plant from Amur Province and Yakutia really belong to L. gracillescens or represent another taxon.

\section{MATERIALS AND METHODS}

Sampling. In addition to L. gracillescens-like plants, we included the most common phenotypes of L. polycarpa from the Russian Far East and Yakutia into the set for sequencing, and specimen from European Russia.

\footnotetext{
1 - Lomonosov Moscow State University, Biological Faculty, Geobotany Dept., Leninskie Gory Str. 1-12, Moscow 119234 Russia - Россия, 119234, Москва, Ленинские Горы, д. 1 стр. 12, Московский государственный университет, биологический факультет, кафедра геоботаники. E-mails: misha_ignatov@list.ru \& arctoa@list.ru

2 - Tsitsin Main Botanical Garden, Russian Academy of Sciences, Botanicheskaya Str., 4, Moscow 127276 Russia - Poccия 127276 Москва, Ботаническая 4, ГБС РАН. E-mail: oikuznets@gmail.com

3 - Joint Stock Company Kama Research Institute on Complex Deep and Superdeep Borehole Investigations, Krasnoflotskaya str., 15, Perm, 614016 Russia. - Россия 614016, Пермь, Краснофлотская, 15, АО «Камский научно-исследовательский институт комплексных исследований глубоких и сверхглубоких скважин». E-mail: bezgodovs@list.ru
} 


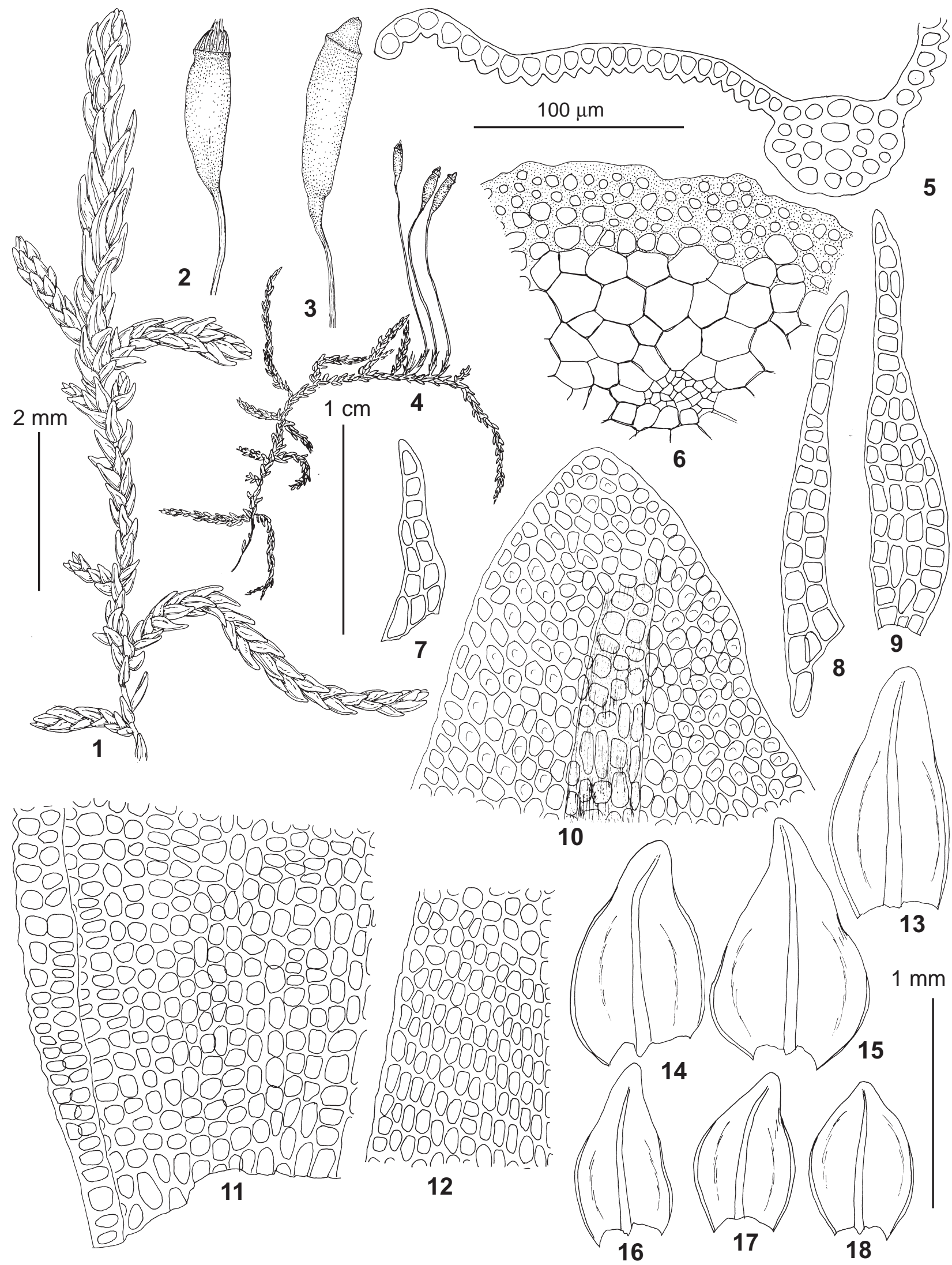

Fig. 1. Leskea polycarpa (from: Russia, Yakutia, Khangalassky Distr., 2.VIII.2016, Ignatov \& Ignatova \#16-160, MHA). 1, 4 - habit, dry; 2-3 - capsules; 5 - leaf transverse section; 6 - stem transverse section; 7-9 - paraphyllia; 10 - upper laminal cells; 11 - basal laminal cells; 12 - median laminal cells; $13-15$ - stem leaves; $16-18$ - branch leaves. Scale bars: $1 \mathrm{~cm}$ for $4 ; 2 \mathrm{~mm}$ for $1-3 ; 1 \mathrm{~mm}$ for $13-18 ; 100 \mu \mathrm{m}$ for $5-12$. 

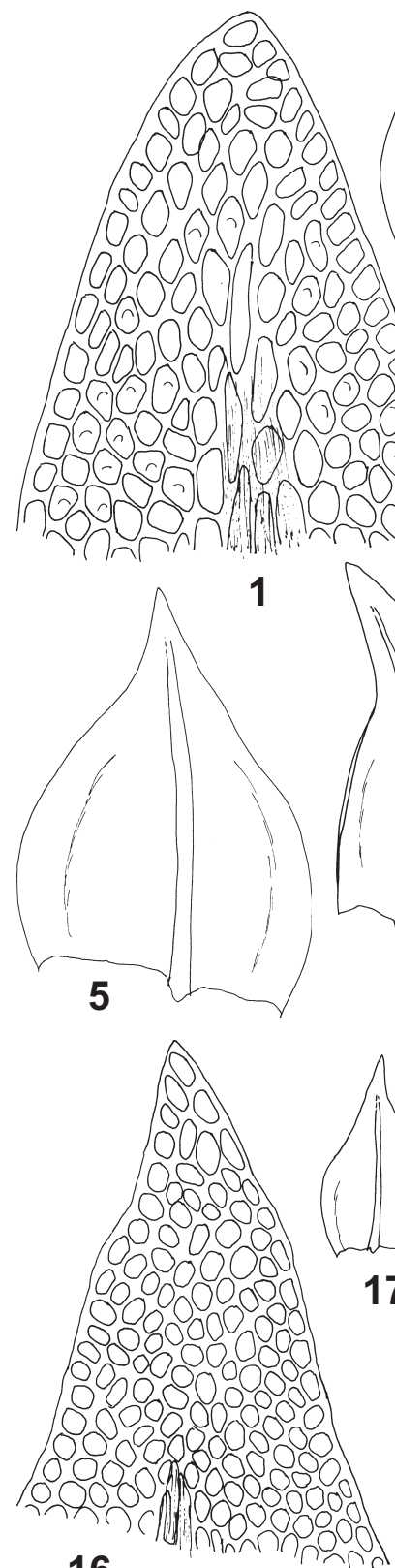

16

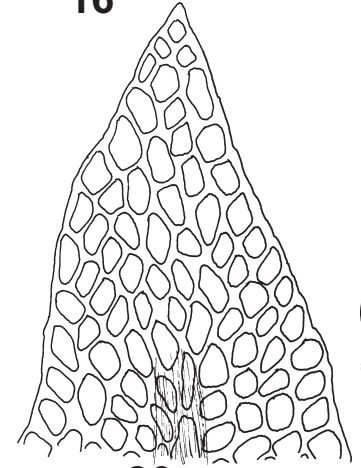

26
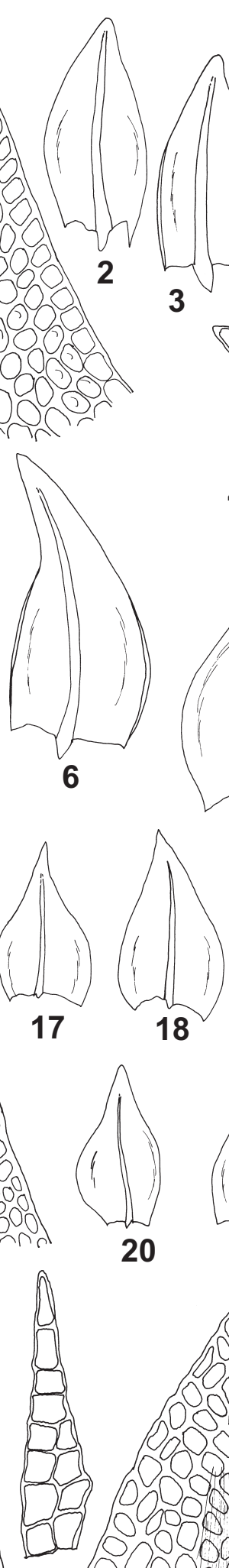

27
18
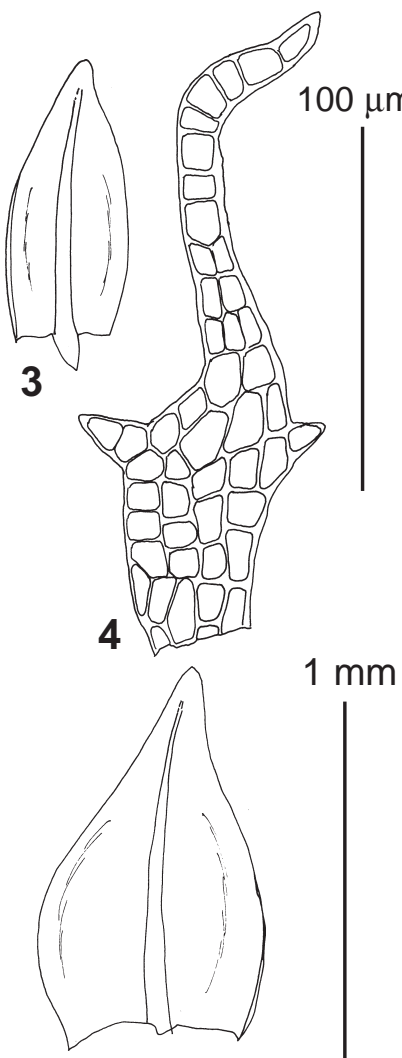

7

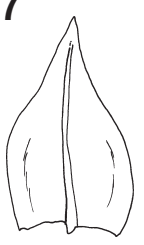

19

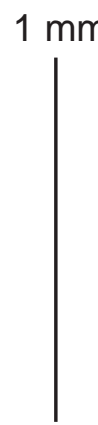

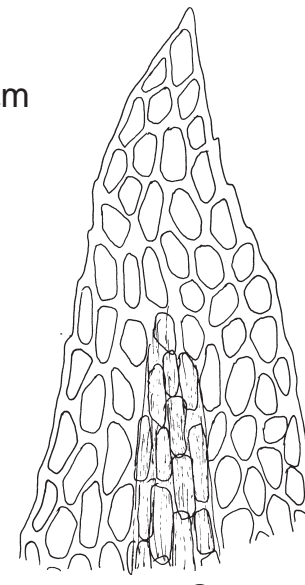
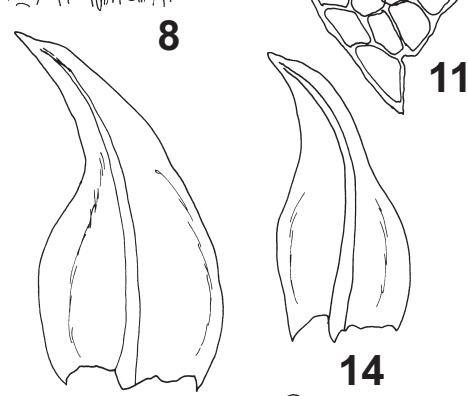

12
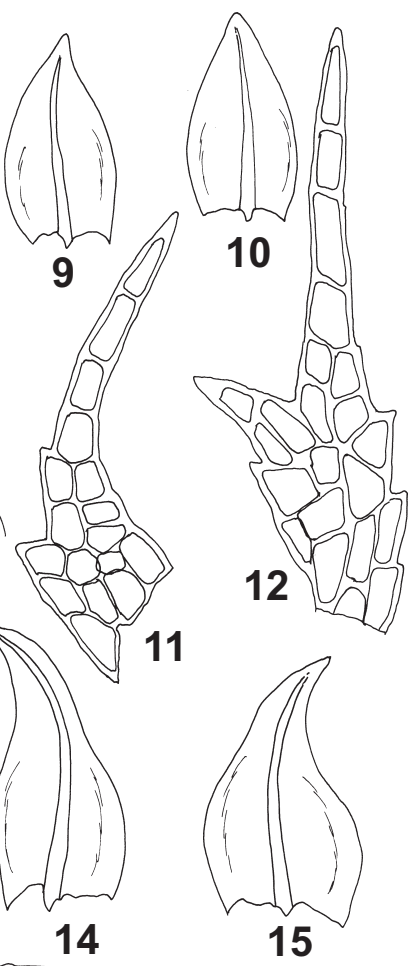

14

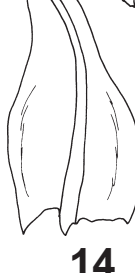

13
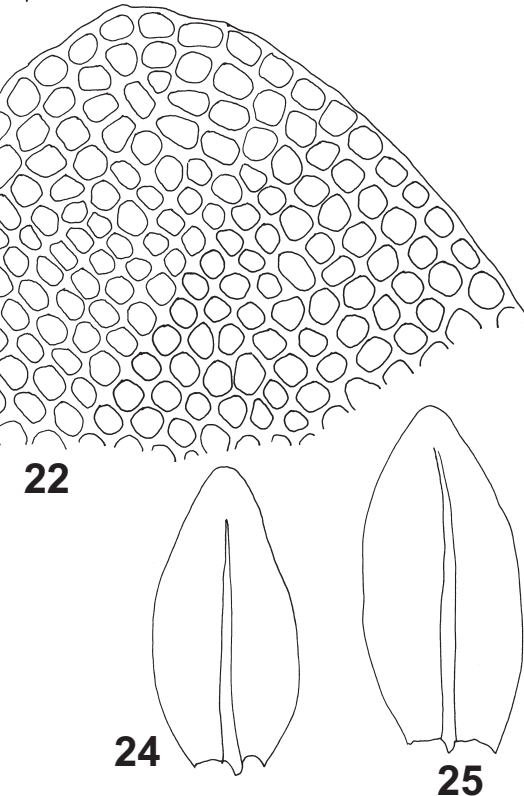

20

21
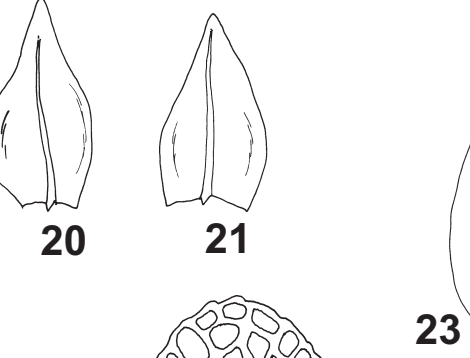

23

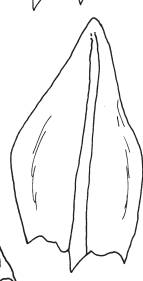

29

\section{8}

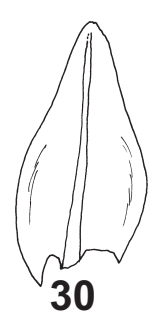

22
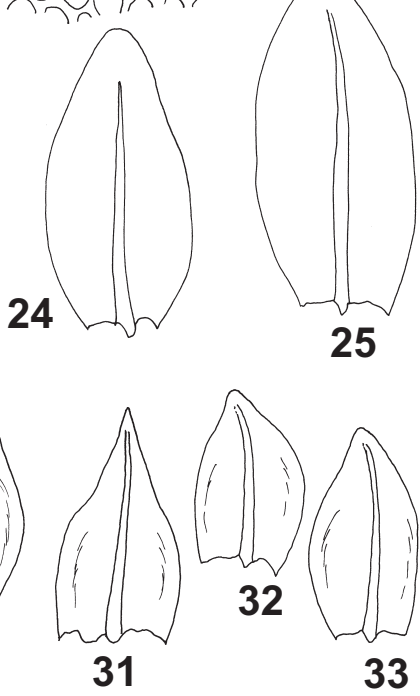

Fig. 2. 1-5 - Leskea polycarpa (1-7 from: Russia, Amursakaya Prov., 1.VII.2010, Bezgodov \#34, MHA; 8-15 - from: Russia, Sakhalin, Pisarenko \#0p03765, MHA); 16-21 - L. gracilescens (from: U.S.A., Ohio, Buck \#50264, NY); 22-25 - L. obscura (from: U.S.A., Buck 22206, NY); 26-33 - L. cf. gracilescens (from: Russia, Amurskaya Prov., 1.VII.2010, Bezgodov \#210, MHA).1, 6, 16, 22, 26, 28- upper laminal cells; 2-3, 9-10, 20-21, 32-33 - branch leaves; 5-7, 13-15, 17-19, 23-25, 29-31 - stem leaves; $4,11-12,27$ - paraphyllia. Scale bars: $1 \mathrm{~mm}$ for $2-3,5-7,9-10,12-15,17-21,23-25,29-33$; $100 \mu \mathrm{m}$ for $1,4,8,11-12,16,22$, $26-28$. 

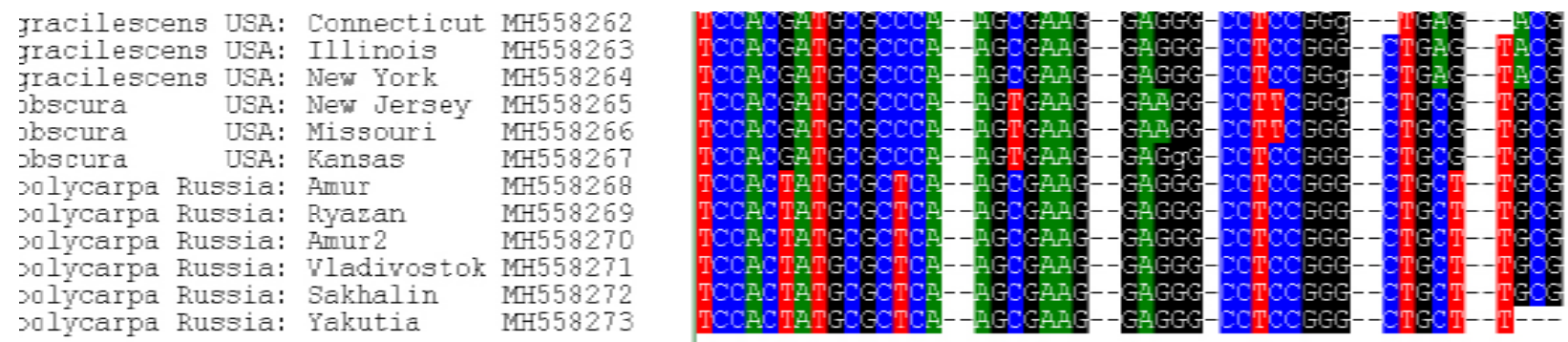

Fig. 3. Five fragments of the ITS alignment of Leskea, showing characteristic substitutions indicating identity of Russian plants of different morphotypes in costrast to American specimens of L. gracilescens and L. obscura. Specimens details are in Table 1 and complete aliggnment in Supplementary materials.

\section{Molecular protocols.}

DNA extraction and amplification were done according to the laboratory protocols described in Gardiner et al. (2005). Vouchers specimens and GenBank accession numbers are listed in Table 1. Sequences were aligned manually in BioEdit (Hall, 1999).

\section{RESULTS}

The molecular results are partly shown in Fig. 3, and complete alignment is given as a supplementary material. There are only very few substitutions between American samples of L. gracilescens and L. obtusa and Eurasian plants, thus we present their distinction by a parts of alignment with substitutions, instead of a tree or haplotype network. The ITS region is found to be variable for separation of these three entities by characteristic substitutions. Among them, L. gracilescens and L. polycarpa lack infraspecific variation in these positions, and $L$. obtusa has one vatiable position.

Specimens from the Amur Province, as well as from Yakutia revealed no differences in sequences from specimens of the common phenotypes of L. polycarpa, both from the Far Eastern and European populations (Fig. 3).

\section{DISCUSSION}

Although the present study results in no taxonomic novelties, the fact of such extreme variation is worthy describing and illustrating (Figs. 1-2). Obviously, the record of L. gracilescens from Russia and probably also from China are based on the ecomorphs of L. polycarpa.

Leaf apices in L. polycarpa are described as 'blunt or acute' in "Moss Flora of North America" (Redfearn Jr., 2008); 'acute to obtuse' in "The moss flora of Britain and Ireland" (Smith, 2004); 'agudo o acuminado' in "Flora bryofítica Ibérica" (Brugués, 2018); "blunt to acute" in "Moss flora of the Middle European Russia" (Ignatov \& Ignatova, 2004). Illustrations in all these floras show slightly secund leaves with more or less oblique apices, only rarely straight and symmetric. This character, along with differentiated stem and branch leaves (stem leaves being longer than wide), is considered as important for separating of $L$. polycarpa from $L$. gracilescens by Redfearn Jr. (2008): L. gracilescens, contrary to L. polycarpa, has straight leaves with symmetrical apices, as well as stem and branch leaves equally hardly longer than wide.

Most Leskea specimens from Russia fully agree with the mentioned features of L. polycarpa, except for the anomalous specimen from Amurskaya Province referred previously to L. gracilescens. In Fig. 2: 1-15, two specimens of $L$. polycarpa from Asian Russia are shown, with clearly asymmetrical stem leaves, oblique leaf apices and less oblong branch leaves with obtuse apices. However, specimen from Amurskaya Province (Fig. 2: 26-33) resembles L. gracilescens from North America (Fig. 2: 1621) rather than L. polycarpa in shape of stem and branch leaves, which are straight and have symmetrical apices. Nevertheless, evidence from molecular markers suggests that this deceiving resemblance is likely caused by the influence of ecological conditions.

Another peculiar specimen with all leaves obtuse, even

Table 1. Specimens of the genus Leskea used in molecular study, with GenBank accession numbers.

Species
L. gracilescens
L. gracilescens
L. gracilescens
L. obtusa
L. obtusa
L. obtusa
L. polycarpa
L. polycarpa
L. polycarpa
L. polycarpa
L. polycarpa
L. polycarpa

Specimen

USA: Connecticut, coll. Tan \#91502 (MHA)

USA: Chicago, 6.X.2013 Ignatov (MHA)

USA: New York, Buck 57814 (NY barcode 1221900)

USA: New Jersey, Buck 22206 (NY barcode 489277)

USA: Missouri, Buck 30103 (NY barcode 489398)

USA: Kansas, Buck 46377(NY barcode 680473)

Russia: Amurskaya Province, 1.VII.2010 \#69 (MHA)

Russia: Ryazan, 11.XI.2009 Donskov (MHA)

Russia: Amurskaya Province, 1.VII.2010 Bezgodov \#34 (MHA)

Russia: Vladivostok, Ignatov \#08-355a (MHA)

Russia: Sakhalin, Pisarenko \#3765 (MHA)

Russia: Yakutia, Ignatov \& Ignatova 16-160 (MHA)

$\begin{array}{ll}\text { Isolate } & \text { Genbank number } \\ \text { OK555 } & \text { MH558262 } \\ \text { OK556 } & \text { MH558263 } \\ \text { OK541 } & \text { MH558264 } \\ \text { OK545 } & \text { MH558265 } \\ \text { OK544 } & \text { MH558266 } \\ \text { OK542 } & \text { MH558267 } \\ \text { OK428 } & \text { MH558268 } \\ \text { OK551 } & \text { MH558269 } \\ \text { OK552 } & \text { MH558270 } \\ \text { OK553 } & \text { MH558271 } \\ \text { OK554 } & \text { MH558272 } \\ \text { OK1438 } & \text { MH558273 }\end{array}$


with rounded apices, was collected in Central Yakutia. However, its stem leaves are more longer than wide in comparison with branch leaves and have slightly oblique apices (Fig. 2), which is in agreement with circumscription of L. polycarpa according to Redfearn Jr. (2008). Capsules in this specimen are also slightly different from common morphotype of $L$. polycarpa, being straight and shorter than usual. However, molecular markers did not reveal any difference between this specimen and other specimens of $L$. polycarpa, pointing on wider morphological variability of this species in peculiar ecological conditions in permafrost areas of Asian Russia with repeated strong summer floods caused by the permafrost melting.

\section{ACKNOWLEDGEMENTS}

The work was supported by RSF (grant no. 18-1400121).

\section{LITERATURE CITED}

[ABRAMOV, I. I.] АБРАМОВ, И.И. 1969. Проблема эндемизма у листостебельных мхов. - [The endemism in the mosses] Комаровские чтения Ботанического института АН СССР. [Komarovskiye chteniya Botanicheskogo Instituta Akad. Nauk SSSR] 22: 1-55.

[ABRAMOVA, A.L., L.I. SAVICZ-LJUBITSKAYA \& Z.N. SMIRNOVA] АБРАМОВА А.Л., Л.И. САВИЧ-ЛЮБИЦКАЯ, З.Н. СМИРНОВА 1961. Определитель листостебельных мхов Арктики CCCP. - [Handbook of mosses of Arctic of the USSR] Л., Изд-во АН CCCP [Leningrad, Izd. Akad. Nauk SSSR], 716 pp.

[ABRAMOV, I. I. \& L. A. VOLKOVA] АБРАMOВ, И.И., Л.А. ВОЛКОВА 1998. Определитель листостебельных мхов Карелии. — [Handbook of mosses of Karelia] Arctoa 7, suppl. 1: 390 pp.

[BEZGODOV, A.G., E.A. IGNATOVA \& M.S. IGNATOV] БЕЗГОДОВ А.Г., Е.А. ИГНАТОВА, М.С. ИГНАТОВ. 2013. Список мхов Норского заповедника. - [List of mosses of the Nora State Reserve] Сборник статей к 15-летию Ноского заповедника (ред. Н.Н. Колобаев), Благовещенск-Февральск, Государственный природный заповедник Норский [In: Kolobaev, N.N. (ed.), Sbornik statey k 15-letiyu Norskogo zapovednika. Blagoveshchensk-Fevralsk, Gosudarstvennyj Pripodnyj Zapovednik Norsky]: 58-78.

BRUGUÉS, M. \& E. RUIZ. 2018. Leskeaceae Schimp. - In Guerra, J. \& R. M. Cros (eds.) Flora bryofitica Iberica. Sociedad Espańola de Briología, Murcia, Spain, pp. 19-35.
CRUM, H. A. \& L. E. ANDERSON. 1981. Mosses of the Eastern North America. Vol. 2. - Columbia University Press, New York. pp. 6641328.

CAO, T., J. SUN \& C. GAO. 2002. Leskeaceae. - In: Wu, P-c. \& M. Crosby (eds.) Moss flora of China, English version. Vol. 6. Hookeriaceae-Thuidiaceae, Science press (Beijing \& New York) \& Missouri Botanical Garden Press, pp. 99-130.

GARDINER, A., M. IGNATOV, S. HUTTUNEN \& A. TROITSKY. 2005. On resurrection of the families Pseudoleskeaceae Schimp. and Pylaisiaceae Schimp. (Musci, Hypnales). - Taxon 54: 651-663.

HALL, T.A. 1999. BioEdit: a user-friendly biological sequence alignment editor and analysis program for Windows 95/98/NT. - Nucleic Acids Symposium Series 41: 95-98.

HEDWIG, J. 1801. Species Muscorum Frondosorum. - Lipsiae. 352 pp.

HILL, M. O., N. BELL, M. A. BRUGGEMAN-NANNENGA, M. BRUGUÉS, M. J. CANO, J. ENROTH, K. I. FLATBERG, J.-P. FRAHM, M. T. GALLEGO, R. GARILLETI, J. GUERRA, L. HEDENÄS, D. T. HOLYOAK, J. HYVÖNEN, M. G. IGNATOV, F. LARA, V. MAZIMPAKA, J. MUŃOZ \& L. SÖDERSTRÖM. 2006. An annotated checklist of the mosses of Europe and Macaronesia. - Journal of Bryology 28: $198-267$.

IGNATOV, M. S., O. M. AFONINA \& E. A. IGNATOVA (eds.). 2006. Check-list of mosses of East Europe and North Asia. - Arctoa 15: 1130.

[IGNATOV, M.S. \& E.A. IGNATOVA] ИГНАTOB M.C., Е.А. ИГНАТОВА 2004. Флора мхов средней части европейской России. T. 2. - [Moss flora of the Middle European Russia. Vol. 2] M., KMK [Moscow, KMK]: 609-960.

REDFEARN JR., P. L. 2014. Leskea. - In: Flora of North America Editorial Committee (eds.) Flora of North America North of Mexico, vol. 28. New York, Oxford University Press: 349-352.

ROS, R. M., V. MAZIMPAKA, U. Y. ABOU-SALAMA, M. ALEFFI, T. L. BLOCKEEL, M. BRUGUÉS, R. M. CROS, M. G. DIA, G. M. DIRKSE, I. DRAPER, W. EL-SAADAWI, A. ERDAG, A. GANEVA, R. GABRIEL, J. M. GONZÁLEZ-MANCEBO, C. GRANGER, I. HERRNSTADT, V. HUGONNOT, K. KHALIL, H. KÜRSCHNER, A. LOSADA-LIMA, L. LUÍS, S. D. MIFSUD, M. PRIVITERA, M. PUGLISI, M. S. SABOVLJEVIC, C. SÉRGIO, H. M. SHABBARA, M. SIM-SIM, A. SOTIAUX, R. TACCHI, A. VANDERPOORTEN \& O. WERNER. 2013. Mosses of the Mediterranean, an annotated checklist. - Cryptogamie Bryologie 34(2): 99-283.

SCHIMPER, W. P. 1860. Synopsis Muscorum Europaeorum. - Stuttgart, E. Schweizerbart, $733 \mathrm{pp}$.

SMITH, A. J. E. 2004. Moss Flora of Britain and Ireland, ed. 2. - Cambridge University Press, Cambridge, England, U.K. 1012 pp. 